\title{
Gene expression profiling in soybean under aluminum stress: genes differentially expressed between Al-tolerant and Al-sensitive genotypes
}

\author{
Dechassa Duressa $^{1,2}$, Khairy M. Soliman ${ }^{1}$, Robert W. Taylor ${ }^{1}$, Dongquan Chen $^{3}$ \\ ${ }^{1}$ Department of Natural Resources and Environmental Sciences, Alabama A\&M University, Normal, Alabama, USA;
${ }^{2}$ USDA-ARS, Salinas, California, USA;
${ }^{3}$ Biostatistics and Bioinformatics Unit, Comprehensive Cancer Center, Division of Preventive Medicine, Department of Medicine,
University of Alabama at Birmingham, Birmingham, USA.
}

Email: ${ }^{1}$ khairy.soliman $@$ aamu.edu

Received 20 July 2011; revised 29 July 2011; accepted 16 August 2011.

\begin{abstract}
It is well documented that aluminum (Al) toxicity is the most important constraint to crop production on acid soils and soybean is one of the most $\mathrm{Al}$ sensitive plant species. To advance our understanding of the molecular and genetic mechanisms of Al-tolerance in soybean we compared root tip (1 cm long) transcriptome profiles of an Al-tolerant (PI 416937) and Al-sensitive (Young) soybean genotypes using a combination of DNA microarrays and quantitative real-time PCR gene expression profiling technologies, in a time-course experiment $(2,12,48,72 \mathrm{~h}$ post $\mathrm{Al}$ treatment). We observed many genes differentially expressed between the two genotypes in constitutive and non-constitutive manner. The most likely candidate Al-tolerance genes expressed at high level in PI 416937 relative to Young include the previously reported transcription factors, auxin down regulated-like protein (ADR6-like) and, basic leucine zipper (bZIP 94), sulfur transmembrane transport protein and lipid transfer protein; and several novel genes that include rare cold inducible protein (RCI2B ), GPI-transamidase, malonyl-COA: Isoflavone 7-O-glucoside-6"-O-malontransferase, a cell proliferation protein (WPP2), oleosin protein, pectinestrease inhibitor, and impaired sucrose induction1; whereas genes negatively correlated with Al-tolerance, namely cellulose synthase and calcium transporters were down regulated in Al-tolerant PI 416937 compared to the Al-sensitive Young. The possible mechanisms of how these genes contribute to Al-tolerance trait are discussed. In conclusion, transcriptome profile comparisons of Al-tolerant and Al-sensitive soybean genotypes revealed novel putative Al-tolerance genes. These genes deserve further
\end{abstract}

functional characterization for eventual utilization in developing soybean germplasm adapted to high aluminum soils.

Keywords: Soybean, Al Tolerance, Gene Expression, Microarray

\section{INTRODUCTION}

Aluminum (Al) toxicity is a major constraint to crop production on acid soils. In view of the fact that $40 \%$ of the world's arable land is acidic [1], Al toxicity remains as a major hurdle for increasing world food production, especially in developing tropical and subtropical regions where increase in food production is much needed. Aluminum reduces crop yield through root growth inhibition and impairment in nutrient and water uptake. Plants tolerate aluminum via several mechanisms that include, 1) exclusion mechanism that involve chelation of aluminum with root secreted organic ligands-mainly citrate, malate and oxalate in the rhizosphere, 2) by possessing low cell wall polysaccharides and, 3) by internal detoxification that involves complexation of $\mathrm{Al}$ in the symplast with organic ligands and subsequent sequestration in the vacuole [2-6]. The level of $\mathrm{Al}$ tolerance varies from species to species and among genotypes within species. Although physiologically a simple trait, the molecular mechanism of $\mathrm{Al}$ tolerance and toxicity largely remains elusive. Two Al tolerance genes Aluminum Induced Malate Transporter 1 (ALMT1) in Arabidopsis [7] and Aluminum Induced Multidrug Exporter (ALMATE) in sorghum [8] have so far been cloned.

Soybean is one of the most $\mathrm{Al}$ sensitive plant species with root growth inhibition of up to $50 \%$ in sensitive cultivars with $\mathrm{Al}^{3+}$ activity of only $1.5 \mu \mathrm{M}$ in culture 
solution [9]. Genetic [10] and physiological analyses [11] show Al tolerance in soybean is a complex trait. In a population derived from a cross between the $\mathrm{Al}$ tolerant genotype PI 416937 and the Al sensitive cultivar Young quantitative trait loci mapping revealed five DNA markers associated with $\mathrm{Al}$ tolerance [10]. Using differential display gene expression profiling [12] identified three genes associated with soybean $\mathrm{Al}$ tolerance namely phosphenopyruvate, carboxylase (PEPC), homologous of translationally controlled tumor proteins (TCTP) and inosine 5'-monophosphate dehydrogenases (IMPDH). Using subtractive hybridization approach [13] identified two putative soybean Al tolerance genes, namely soybean aluminum induced 3-2 (Sali3-2) and soybean aluminum induced 5-4a (Sali5-4a). The two research groups $[12,13]$ used a pair of Al tolerant and sensitive genotypes to identify genes specifically regulated by $\mathrm{Al}$ in the tolerant types, however, the methods used were not sensitive enough to detected cascade of genes and pathways involved in soybean $\mathrm{Al}$ tolerance and toxicity. The aim of the present work was to identify candidate soybean Al-tolerance genes using the Al-tolerant soybean PI 416937 and the Al-sensitive Young employing the technique of DNA microarrays to understand specific gene function related to $\mathrm{Al}$ tolerance trait. Such approach was recently used in wheat [14,15], maize [16], Medicago truncatula [17,18] and Arabidopsis [19] to discern the molecular basis of $\mathrm{Al}$ tolerance in the respective species.

\section{MATERIALS AND METHODS}

\subsection{Plant Genotype and Growth Conditions}

Soybean plant introduction (PI 416937) is well characterized for its Al-tolerance, including exclusion of $\mathrm{Al}$ from entering root tip [11,47]. Al -sensitive soybean genotype Young served as a control. Seeds were surface sterilized with $20 \%$ clorox $(\mathrm{v} / \mathrm{v})$ for 12 minutes, rinsed with distilled-deionized water several times, and were germinated in deionized water moistened germination paper at $25^{\circ} \mathrm{C}$ in an incubator for 72 hours. Seedlings with uniform tap root length from the germinated seeds were transferred to black painted pots filled with approximately $4 \mathrm{~L} 800 \mu \mathrm{M} \mathrm{CaCl}_{2}$ solution with 0 or $10 \mu \mathrm{M}$ $\mathrm{Al}$ in Conviron growth chamber (16/8 hour light/ dark cycle, temp. $28^{\circ} \mathrm{C} / 20^{\circ} \mathrm{C}$, photosynthetic photon density of $100 \mu \mathrm{mol} \mathrm{m}^{-2} \mathrm{~s}^{-1}$ ). The $\mathrm{pH}$ of the culture solution was adjusted to 4.3. After 2, 12, 48 or $72 \mathrm{~h}$ of exposure to $\mathrm{Al}$ treatment, $0-1 \mathrm{~cm}$ section of the primary root tips of approximately 15 plants per pot were harvested and immediately flash-frozen in liquid nitrogen, and stored at $-70^{\circ} \mathrm{C}$ for RNA extraction. Three independent replicates were used per treatment.

\subsection{RNA Extraction, Microarray Procedure and Data Analysis}

Total RNA was extracted from $100 \mathrm{mg}$ root tissue samples using a Qiagen RNeasy plant RNA isolation kit following manufacturer's protocol (Qiagen, Inc.). The Affymetrix GeneChip Soybean Genome Array with over 68,000 probe sets Glycine Max L. and wild soybean combined was used for microarray analysis of the soybean genome for $\mathrm{Al}$ tolerance. Three chips were used per treatment. Detailed procedures for RNA labeling and array analysis are described in the Affymetrix GeneChip Expression Technical Manual. Briefly, the quality of total RNA was determined using RNA 6000 Nano chip on the Agilent BioAnalyzer 2100 prior to double-stranded cDNA synthesis. Total RNA in the amount of $2 \mu \mathrm{g}$ was used for double-stranded cDNA generation by linear amplification using oligo dT-T7 primer and reverse transcriptase (RT). Subsequently, biotin-labeled cRNA was synthesized by in vitro transcription (IVT) using ENZO High Yield IVT kit (ENZO). Quality and quantity of cRNA was assessed using RNA 6000 Nano chip on Agilent BioAnalyzer 2100. Fifteen microgram cRNA was used for hybridization. Arrays were hybridized overnight at $45^{\circ} \mathrm{C}$ for 16 hours in a GeneArray Hybridization Oven 640 (Affymetrix). The next day arrays were washed and stained in the Fluidics Station 450 (Affymetrix) and scanned by the High Resolution Gene Chip Scanner 3000 (Affymetrix).

Gene expression levels were determined using Gene Chip Operating Software (GCOS 1.1, Affymetrix). The expression levels were subjected to data query and data mining in Data Mining Tool (DMT). Statistical analysis of the data was conducted using the software packages Array Assist Enterprise together with Pathway Architect (Stratagene/Agilent, Santa Clara, CA). Briefly, the raw Gene Chip files (Cel and CHP) from Gene Chip Operating Software (GCOS, Affymetrix, CA) were uploaded, background-subtracted, variance stabilized, and normalized with the GC-RMA method [48]. Gene expression level of the control treatment was used as a baseline to calculate the intensity ratio/fold changes (FC). The ratio was $\log 2$-transformed before further statistical analysis. The p-values were obtained by an unpaired t-test assuming unequal variance. Significantly up-regulated and down-regulated genes were annotated using non-redundant protein databases accessed by BLASTX at National Center for Biotechnology Information (NCBI).

\subsection{Quantitative Real-Time PCR}

Quantitative real-time PCR analysis was employed to validate the relative change in expression of genes for selected gene panels from microarray experiments using the Roche Diagontics light Cycler $^{\mathbb{B}} 480$ System with 
SYBR green detection format (Roche Diagnostic, Corp). RNA extraction and quality test was as described above. Prior to cDNA synthesis, RNA samples were treated with Applied Biosystems Turbo DNAse-free ${ }^{\mathrm{TM}}$ DNase (Ambion, Inc.,) to remove DNA contamination. Briefly, $2 \mu 1$ 10x DNase I buffer and $1 \mu \mathrm{l}$ rDNase I were added to $20 \mu 1$ RNA sample and the mix was incubated at $37^{\circ} \mathrm{C}$ for $30 \mathrm{~min}$ in water bath. Afterwards, $2 \mu 1$ re-suspended DNase inactivation reagent was added and the samples mixed well and incubated at room temperature for $3 \mathrm{~min}$. Samples were then centrifuged at $10,000 \mathrm{x}$ g for $1.5 \mathrm{~min}$ (Eppendorf centrifuge $5415 \mathrm{D}$ ) in $1.6 \mathrm{ml}$ centrifuge tubes and the supernatants were transferred to fresh tubes.

cDNA was synthesized from DNase treated RNA samples using a Roche Diagnostics Transcriptor First Strand cDNA Synthesis Kit (Roche Diagnostics, Corp) was as follows. Prior to the procedure, reagents and samples were thawed on ice and reagents were briefly centrifuged at 10,000 rpm. A cDNA synthesis reaction was set-up in $0.5 \mathrm{ml}$ PCR tubes with $1 \mu \mathrm{g}$ total RNA, 1 $\mu 1$ of Oligo (dT) primer, $4 \mu \mathrm{l}$ reaction buffer, $0.5 \mu \mathrm{l}$ RNase inhibitor, $2 \mu 1$ deoxyribonucleotides ( $1 \mathrm{mM}$ each), and $0.5 \mu 1$ reverse transcriptase added in that order. Samples were brought to $20 \mu 1$ total reaction volume with PCR grade water and centrifuged for 1 min @ 340 rpm (Ep-pendorf centrifuge 5804R), incubated at $55^{\circ} \mathrm{C}$ for $30 \mathrm{~min}$. Reverse transcriptase was inactivated by an additional incubation for $5 \mathrm{~min}$ at $85^{\circ} \mathrm{C}$, all in a DNA Engine (PTC-200) thermocycler (MJ-research). The cDNA concentration and quality was determined using Nano-Drop Spectrophotometer brand ND-1000 (NanoDrop Technologies, Inc. A total reaction volume of $11 \mu \mathrm{l}$ comprising $2 \mu \mathrm{l}$ cDNA sample, $2 \mu 1$ each of the reverse and forward primers at $0.2 \mu \mathrm{M}$ concentration and $5 \mu \mathrm{l}$ SYBR mix was prepared in 96-well plates (Roche Diagnostics) in two biological and three technical replicates for each gene. The real-time PCR profile was $95^{\circ} \mathrm{C}$ for $5 \mathrm{~min}, 45$ cycles of amplification at $95^{\circ} \mathrm{C}$ for $10 \mathrm{sec}-$ ond, $55^{\circ} \mathrm{C}$ for 20 second and $72^{\circ} \mathrm{C}$ for 20 second, and melting $95^{\circ} \mathrm{C}$ for $1 \mathrm{~min}, 65^{\circ} \mathrm{C}$ for $1 \mathrm{~min}$ and $95^{\circ} \mathrm{C}$ continuous, and cooling at $40^{\circ} \mathrm{C}$ for 30 second. Negative controls, in which cDNA sample was replaced with PCR grade water for each primer pairs, were included in each run. Sample wells were individually assessed for data quality and PCR product specificity was verified by melting curve analysis. Expression level of target genes was normalized using in-run beta tubulin gene as internal control and transcript concentration ratios were calculated using the $\Delta \Delta \mathrm{CT}-$ Method [49]. Fold change was calculated as treatment to control ratio and correlated with results from microarray.

\section{RESULTS AND DISCUSSION}

\subsection{Principal Component Analysis (PCA), (A)}

Principal component analysis was conducted to evaluate whether or not the two genotypes differ in gene expression pattern. The results clearly demonstrated that the two genotypes had a distinct transcriptome profile (Figure 1). An assessment of genes differentially expressed between the genotypes revealed that the majority of the genes are constitutively expressed at higher or lower levels in PI 416937 compared to Young (Figure 4), a reflection of genetic background difference. By fitting an ANOVA model to gene expression data in a maize Al study [16] observed large genotypic effect and small treatment effect, consistent with our finding.

\subsection{Overall Assessment of Gene Expression Changes (B)}

The number of genes differentially expressed between PI 416937 and Young increased with treatment time peaking at $72 \mathrm{~h}$ post treatment (Figures 2, 3). The ratio of up-regulated to down-regulated genes was 52/20, 71/41, $61 / 56$ and $137 / 786$ for $2,12,48$, and $72 \mathrm{~h}$, respectively. These results also show that more genes were up-regulated in Young as exposure time to Al treatment increased indicating that the sensitive genotypes responds in a nonspecific manner the longer the treatment duration, likely, as a syndrome of Al toxicity rather than a mechanism of tolerance. Similar results were reported by [16] in maize and [18] in Medicago truncatula.

To determine the type of induction of genes differenttially expressed, the two genotypes were further compared with or without aluminum treatment. The results demonstrated that the majority of the genes are either constitutively up- or down-regulated in PI 416937 in comparison to Young (Figure 4), suggesting that perhaps the constitutive nature of the $\mathrm{Al}$ tolerance mechanism is genetically inherited, that is, an Al tolerant genotype has genes that are expressed at high level compared to the sensitive genotype in the absence or presence of Al. This conclusion would not have been possible without making control to control comparison of tolerant vs. sensitive genotype pairs as was done here. These results are corroborated by findings of [7] in wheat, [8] in sorghum, and [20] in barley; that the malate and citrate transporters $\mathrm{Al}$ tolerance genes cloned so far are constitutively expressed at high level in tolerant compared to sensitive genotypes. Classification of the differentially expressed genes based on cellular function shows that $12 \%$ is related to stress response, $9 \%$ to transport, $5 \%$ to signaling, $5 \%$ to cell structure, and 3\% to transcription factors. The remaining $42 \%$ is comprised of genes of unknown function (Figure 5). 


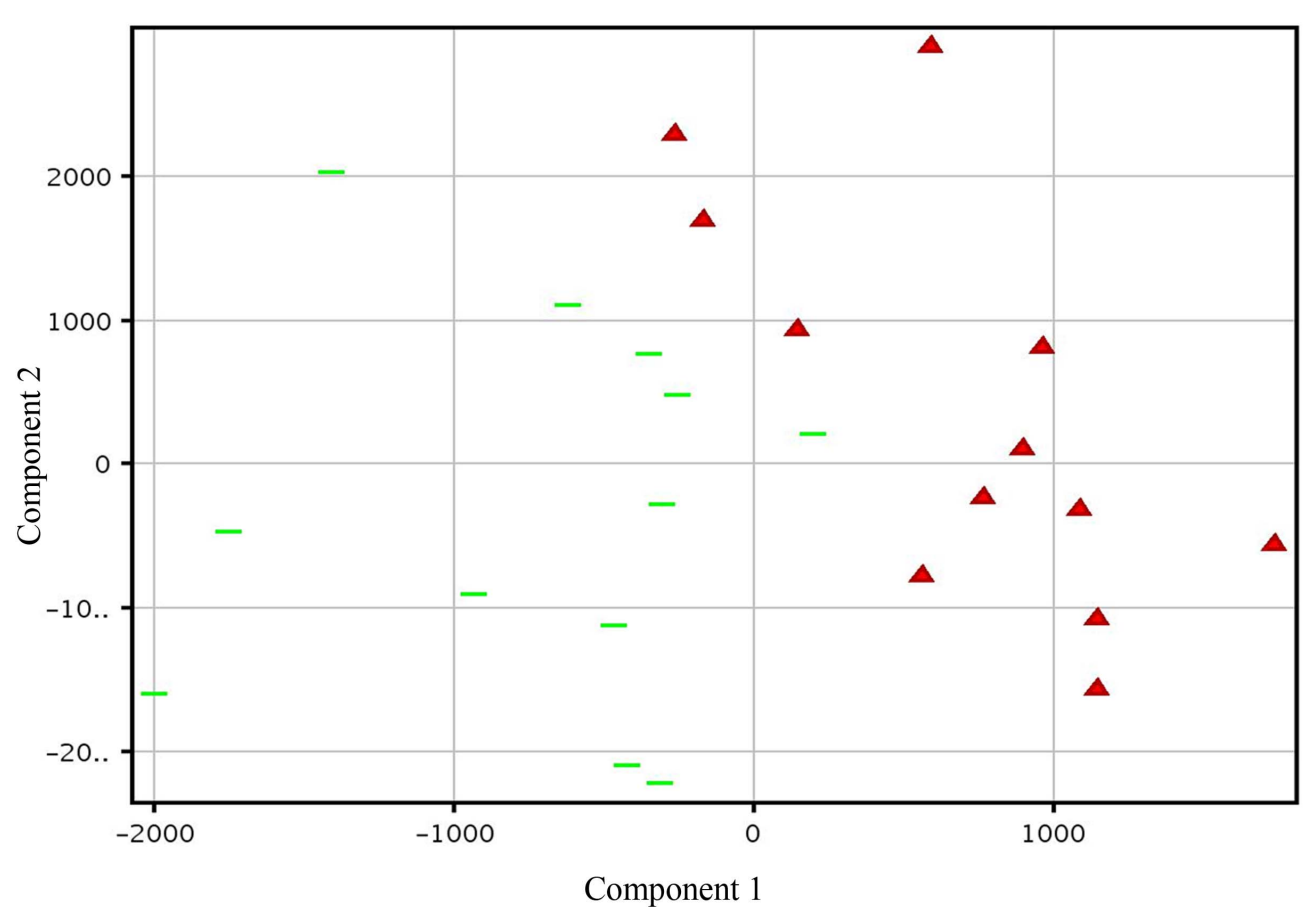

Figure 1. Principal Component Analysis (PCA) of genotypic gene expression profiles based on 24 chips with or without aluminum combined. Red triangles (PI 416937) green bars (Young). A clear separation of the gene expression profiles of the genotypes is shown.

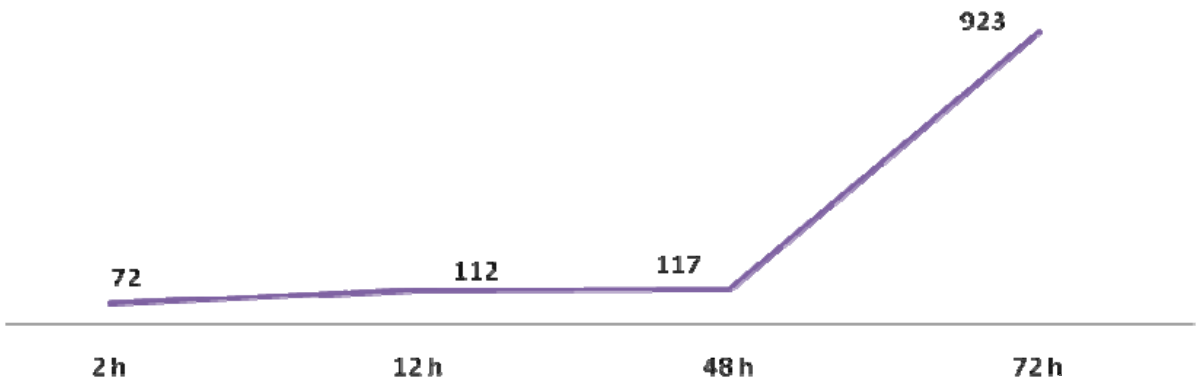

Figure 2. Number of differentially expressed genes as a function of aluminum treatment time (h) in PI 416937 vs. Young comparisons.

\subsection{Differentially Expressed Genes by Functional Category (D)}

\subsubsection{Genes Related to Transcription Factors}

Classification of genes differentially expressed between PI 416937 and Young based on cellular function showed that the number of transcription factors detected was small, constituting only $3 \%$ of the total expressed genes (Figure 5). At $2 \mathrm{~h}$ post treatment the homeobox transcription factor (Gma. 24251) was up-regulated by $\approx 13$ fold (Table 1). In a similar study [23] identified the homeobox domain transcription factor as the regulator of cold tolerance in Arabidopsis in addition to its regu- latory effect on plant growth and development. At $12 \mathrm{~h}$ post Al treatment two transcription factors WRKY70 (Gma.4281) and basic-helix-loop helix (Gma.16666) were down-regulated (Additional file 1). The ADR6-like transcription factor (Gma.28057) previously reported by [13] was up-regulated 5.18 fold at $48 \mathrm{~h}$ post treatment (Additional file 2). A basic leucine zipper (bZip94) transcription factor (Gma.17306) was up-regulated 5.18 and 6.45 fold at $48 \mathrm{~h}$ and $72 \mathrm{~h}$, respectively, in a constitutive manner. In the legume family, bZip transcription factors are reported to regulate drought stress response and seed development in Phaseolus species and pathogen defense response and plant development in soybean [24]. 


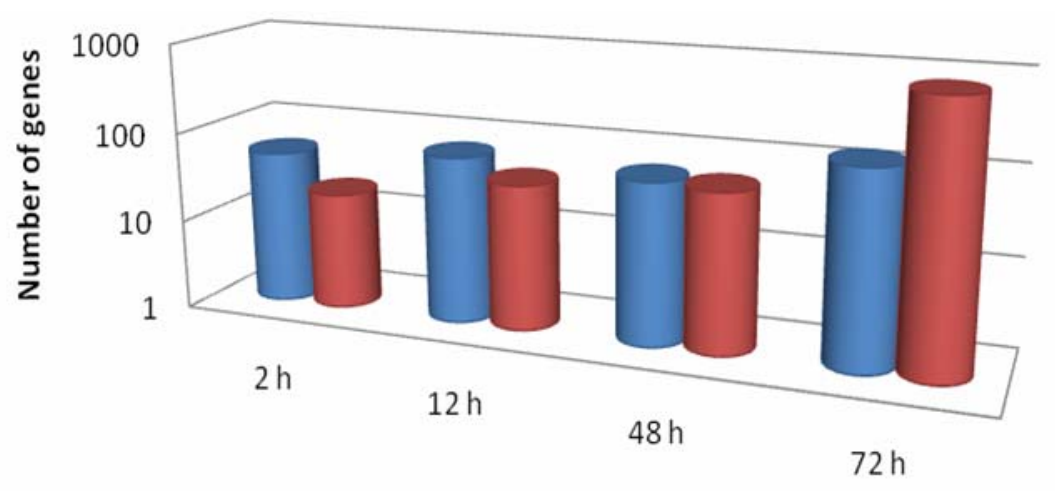

\begin{tabular}{|l|c|c|c|c|}
\cline { 2 - 5 } \multicolumn{1}{c|}{} & $2 \mathrm{~h}$ & $12 \mathrm{~h}$ & $48 \mathrm{~h}$ & $72 \mathrm{~h}$ \\
\hline$\square$ up & 52 & 71 & 61 & 137 \\
\hline adown & 20 & 41 & 56 & 786 \\
\hline
\end{tabular}

Figure 3. Number of up-regulated and down-regulated genes at each time point in PI 416937 vs. Young comparison $(\mathrm{P}<0.01 ; \mathrm{FC}>3)$.

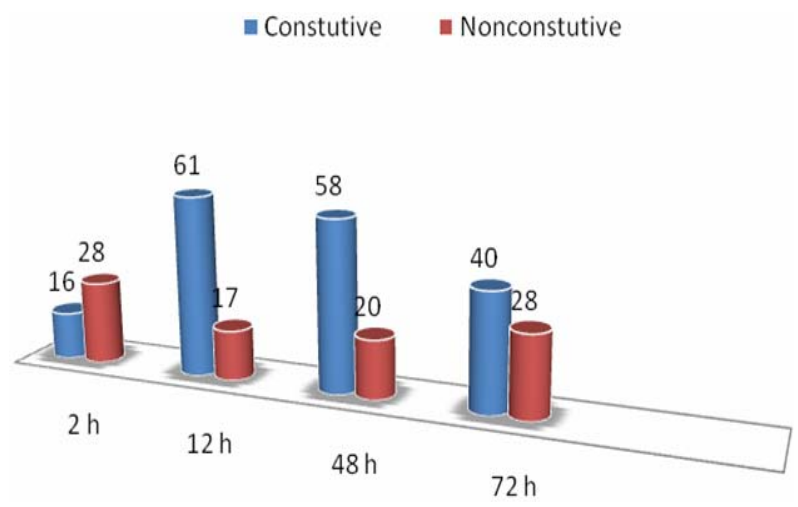

Figure 4. Number of constitutive and non constitutive genes differentially expressed between PI 416937 and Young in time-course experiment.

\subsubsection{Genes Related to Transporters}

Regulated influx and efflux of substances across biological membranes is a vital component of cellular stress responses. Several classes of transporters, symporters and antiporters, lipid transfer proteins, carbohydrate transporters, sulfate trans-membrane transporters, and (ATPase) inward rectifier potassium channel were differentially expressed between PI 416937 and Young. At $2 \mathrm{~h}, \mathrm{k}+-$-ATPase inward rectifier of potassium channel was up-regulated 8.54 fold (Table 1). Potassium plays important roles in biological systems ranging from maintenance of membrane potential, electrical neutralization of ionic groups, osmoregulation, and control of cell membrane polarization, ion homeostasis, enzyme activation, signal transduction and many other physiological functions [25]. These results are consistent with the finding that potassium channel has been shown to be up-regulated [25] during early stages of plant exposure

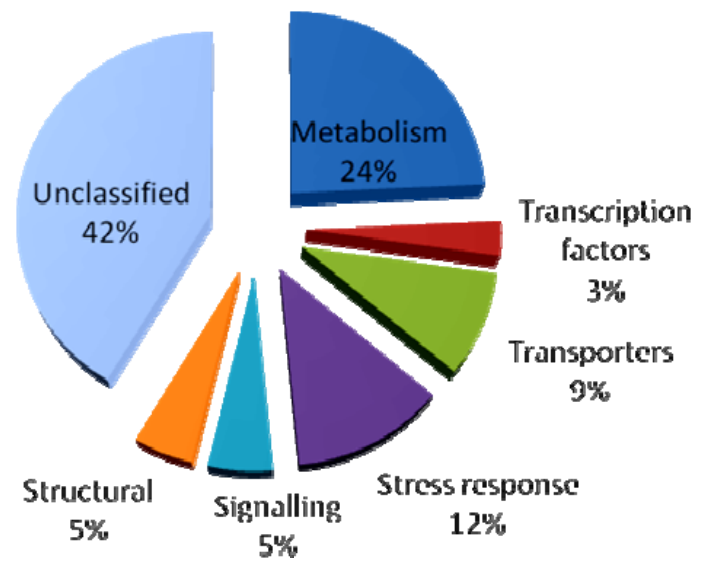

Figure 5. Functional category of genes differentially expressed between PI 416937 and Young.

to cold, drought, salt stress and abscisic acid. Sec 14 cytosolic factor family protein-a lipid transport protein (Gma.34414) was consistently up-regulated at 12, 48, and $72 \mathrm{~h}$ with a fold change of over 11 times in a constitutive manner (Additional files 1, 2 \& 3). Furthermore, another lipid transfer protein (Gma.3880) was up-regulated by $9.15,6.79$, and 13.89 fold at 12,48 and $72 \mathrm{~h}$ respectively. Lipid transport proteins facilitate transport of lipids to cell walls for biosynthesis of cutin layers and surface waxes as a defense mechanism in response to pathogen attack [26]. They are also induced by abiotic stresses including aluminum stress in wheat roots [14]. A recent report by [27] suggests that lipid transport proteins loosen cell wall in a nonhydrolytic mode and enhance cell elongation, the role traditionally attributed to expansin. Aluminum stress inhibits root growth by restricting cell wall expansion. The higher expression level 


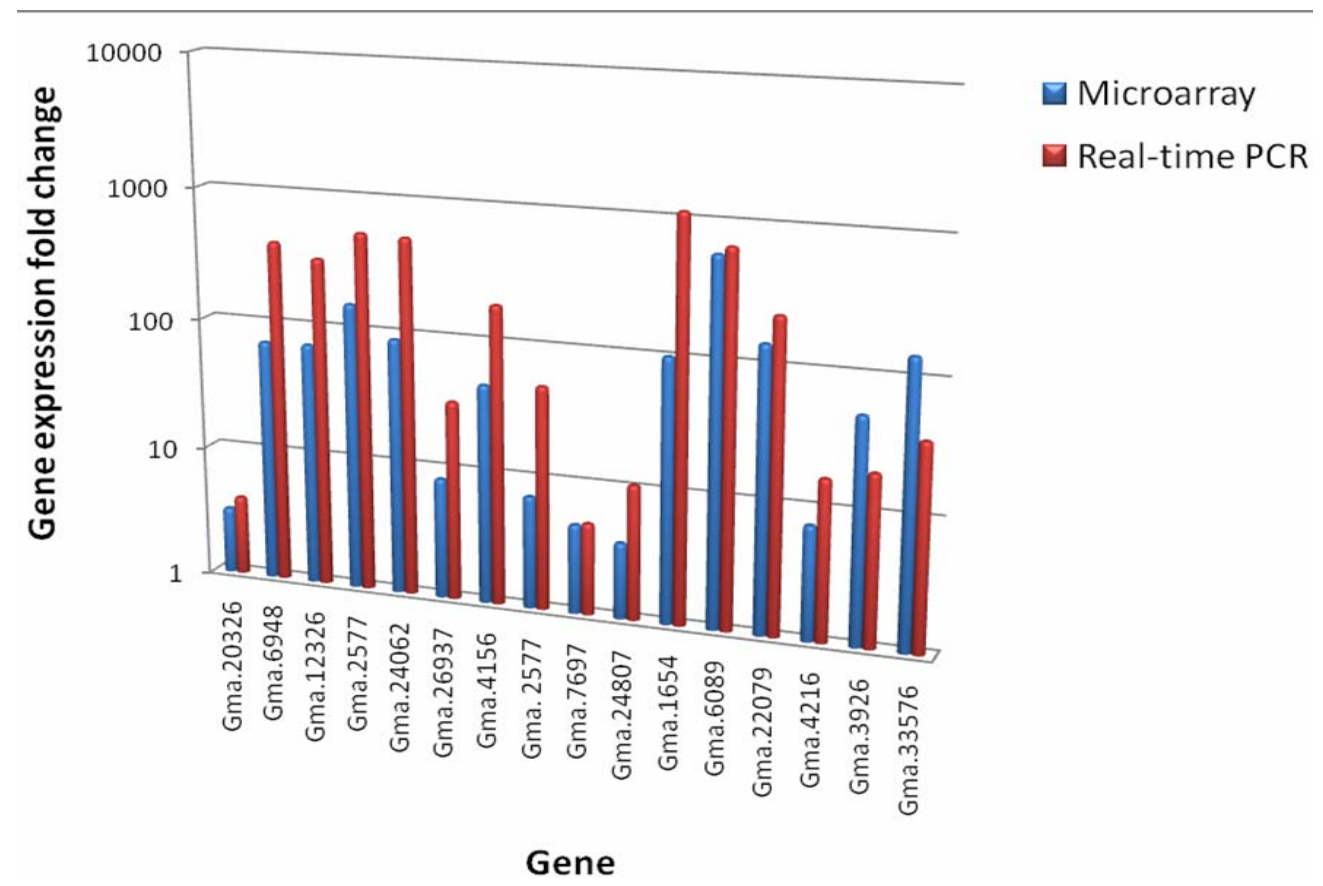

Figure 6. Comparison of microarray and quantitative real-time gene expression in fold change for selected gene panels.

of lipid transfer proteins in $\mathrm{Al}$ tolerant soybean suggests a role for these proteins in soybean $\mathrm{Al}$ tolerance mechanisms. Sulfate trans-membrane proteins Gma.37580 (12 h, Additional file 1) and Gma. 1728097 (72 h, Additional file 3) were constitutively expressed more than 4 fold in PI 416937 compared to Young. Sulfate is a negatively charged ion and could possibly be exuded by roots as Al chelator similar to organic acid anions, phenolics and phosphate [1]. Two Calcium antiporters genes Gma 42414 (12 h, Additional file 1) and Gma.468 (48 h, Additional file 2) were constitutively expressed at approximately 4 fold lower in PI 416937 than in Young. Disruption of cellular calcium homeostasis by calcium influx to cytoplasm has been suggested as the primary trigger of the Al toxicity syndrome [28]. Aluminum increases cystosolic calcium activity that leads to disrupttion in physiological and biochemical processes and ultimately reduced growth. The expression of calcium antiporters/secondary calcium transporters at low level in Al tolerant PI 416937 suggests maintenance of calcium homeostasis under $\mathrm{Al}$ stress in this genotype. Plant sugar transporters are induced by pathogen attack to meet the energy demand imposed on cells under stress [29]. Similarly, Al stress has been shown to cause mitochondrial dysfunction and ATP depletion [30]. Several investtigators [19] identified multiple Al induced sugar transporters in Arabidopsis. In this study, one sugar: hydrogen antiporter gene Gma.17205 was constitutively expressed at 4 fold higher in PI 416937, 12 and $48 \mathrm{~h}$ post treatment (Additional files $1 \& 2$ ).

\subsubsection{Genes Related to Stress Response}

It has been known that plants have developed defense responses to biotic and abiotic stresses over evolutionary time as a survival mechanism. Regulation of gene expression in response to a stress factor is a key component of such response at the molecular level. Aluminum toxicity triggers perturbation in cellular processes and in response induces change in gene expression in both tolerance related genes-mechanism of $\mathrm{Al}$ tolerance; and stress associated genes-a manifestation of $\mathrm{Al}$ toxicity. As one criterion for distinguishing between genes expressed as manifestation of $\mathrm{Al}$ toxicity and genes associated with Al tolerance, genes differentially expressed between an Al tolerant and sensitive genotypes were considered in discussion of this paper. Several stress related genes showed differences in expression level in Al tolerant PI 416937 compared to Al sensitive Young. Several pathogenesis related proteins, oxidative stress related proteins, chaperonin proteins, heat shock proteins, desiccation related proteins, and cold stress related proteins were differentially expressed between the two genotypes. A rare cold inducible gene-RCI2B (Gma.27795) was constitutively expressed at $223.73,257.05$, and 253.35 fold higher in PI 416937 at 2, 48, and $72 \mathrm{~h}$, respectively (Table 1 , Additional files $2 \& 3$ ). This gene was not previously reported in plant $\mathrm{Al}$ literature and is probably a key novel Al tolerance gene in soybean, and thus would be an interesting candidate gene for further characterization. Its molecular mechanism of action is not yet known. In 
Table 1. Genes significantly $(\mathrm{p}<0.01, \mathrm{FC}>4)$ expressed at higher or lower level in PI 416937 compared to Young $2 \mathrm{~h}$ post aluminum treatment.

\begin{tabular}{|c|c|c|c|}
\hline Unigene ID & Fold Change & Functional Category & Annotationb \\
\hline Gma.27795c & 223.73(up) & stress response & RCI2B/response to cold \\
\hline Gma.17961 & 29.73(up) & structural & $\begin{array}{l}\text { glycine rich protein/oleosin protein, lipid sequestration } \\
\text { le-20 }\end{array}$ \\
\hline Gma.15007 & 23.55(up) & metabolism & $\begin{array}{l}\text { ferredoxin } 2 \text { electron carrier/ Photosynthetic electron } \\
\text { transfer chain }\end{array}$ \\
\hline Gma.17744c & 21.99(down) & stress response & gluthatione-s-transferase29 \\
\hline Gma.6487 & 18.31(up) & unclassified & unknown \\
\hline Gma.7535c & 17.96(up) & stress response & $\begin{array}{l}\text { malonyl-COA: isoflavone 7-O-glucoside-6"- } \\
\text { O-malontransferase }\end{array}$ \\
\hline Gma. $21391^{\mathrm{c}}$ & 12.91(up) & unclassified & unknown \\
\hline Gma.5672 & 13.97(up) & metabolism & asparagines synthase 2 \\
\hline Gma.24251 & 12.89(up) & transcription factor & homebox 7 transcription factor \\
\hline Gma.23189 & 12.60(up) & metabolism & hydrolase/metabolic process \\
\hline Gma.9092 & 10.82(up) & unclassified & hypothetical protein \\
\hline Gma.10987 & 10.62(up) & metabolism & Rubsico activase \\
\hline Gma. $5716^{\mathrm{c}}$ & 10.34(up) & unclassified & unknown \\
\hline Gma.2098 & 10.19(up) & unclassified & unknown \\
\hline Gma.22527 & 9.70(up) & unclassified & unknown \\
\hline Gma.6245c & 9.53(up) & stress response & pathogenesis related thaumatin family protein \\
\hline Gma.5568c & 9.53(up) & stress response & germin like protein/metal ion binding in apoplast \\
\hline Gma.17291 & 9.42(up) & unclassified & unknown \\
\hline Gma.1134 & 8.54 (up) & transport & $\mathrm{K}+\mathrm{ATPase} /$ inward rectifier potassium channel \\
\hline Gma. $4434^{c}$ & 7.91(down) & unclassified & $\begin{array}{l}\text { plastocynanin like domain protien/copper ion binding in } \\
\text { memberane }\end{array}$ \\
\hline Gma.13640 & 7.89(down) & metabolism & cellulose synthase like-3/cellulose synthase activity \\
\hline Gma.2166 & 7.88(up) & cell signaling & protein kinase family protein/Phosphorylation function \\
\hline Gma.19712 & 7.8(down) & unclassified & unknown \\
\hline Gma.5672 & 7.79(up) & unclassified & unknown \\
\hline $\mathrm{BI} 316842$ & 7.72(up) & unclassified & unknown \\
\hline Gma. $9683^{\mathrm{c}}$ & 7.64(up) & unclassified & unknown \\
\hline Gma.16838 & 7.25(up) & metabolism & photosystem I subunit $\mathrm{H}-2$ \\
\hline Gma. $395^{\mathrm{c}}$ & 6.42 (up) & metabolism & WPP2 domain protein/lateral root development/mitosis \\
\hline Gma. $17162^{\mathrm{c}}$ & 6.30(up) & unclassified & hypothetical integral membrane protein \\
\hline Gma. $33691^{\mathrm{c}}$ & 5.80 (up) & stress response & quinine reductase family protein/oxidoreductase \\
\hline Gma. $3314^{\mathrm{c}}$ & 5.53(up) & stress response & $\begin{array}{l}\text { cysteine proteinase inhibitor/cysteine type } \\
\text { endo-peptidase inhibitor activity }\end{array}$ \\
\hline Gma.36991 & 5.03(up) & metabolism & beta-xylosidase/hydrolase-hydrolysis O-glycosyl cpds \\
\hline Gma.32786 & 4.98(up) & metabolism & caleosin-related protein/lipase activity \\
\hline Gma. $27015^{\mathrm{c}}$ & 4.68(up) & cell signaling & octicosapeptide PB1 domain protein \\
\hline Gma.5609c & 4.66(down) & metabolism & pyrophosphorylase4/pyrophosphatase-metabolic process \\
\hline Gma. $11191^{\mathrm{c}}$ & 4.66(down) & unclassified & hypothetical protein \\
\hline Gma.15538 & 4.39 (up) & stress response & glutaredoxin protein/arsenate reductase \\
\hline Gma.1783 & 4.28(up) & metabolism & 2-oxoglutarate dependent dioxgenase/hydrolase \\
\hline Gma.10731 & 4.11(up) & metabolism & photo system II subunit O-2/oxygen evolving \\
\hline Gma.15 & 4.02(up) & stress response & LEAS protein/desiccation protective \\
\hline Gma.681 & 4.02(up) & unclassified & unknown \\
\hline BI787321 & 4.00(up) & unclassified & hypothetical protein \\
\hline Gma.4613 & 4.00 (up) & structural & $\begin{array}{l}\text { rubber elongation factor (REF) protein binds to rubber } \\
\text { particles }\end{array}$ \\
\hline Gma.47043.99 (up) & & unclassified & unknown \\
\hline
\end{tabular}

${ }^{\mathrm{a}}$ significance thresholds (fold change $\left.\geq 4, \mathrm{p} \leq 0.01\right),{ }^{\mathrm{b}} \mathrm{e}$-value $(<\mathrm{e}-10)=$ the probability that the match has no biological basis, ${ }^{\mathrm{c}}$ constitutively expressed, ${ }^{\mathrm{d}}$ up $=$ up-regulated in PI 416937 relative to Young, down = down-regulated in PI 416937 relative to Young. Note: constitutively expressed means the gene is expressed at higher or lower level in PI 416937 relative to Young with or without aluminum treatment. 
Arabidopsis [31] demonstrated that the expression of this gene is negatively regulated by light but induced in etiolated seedlings and roots of adult plants. Also, transgenic plants over-expressing this gene had enhanced tolerance to salt and dehydration. Its higher expression level in a drought and aluminum tolerant soybean line here suggests it might confer multi-stress tolerance. Oxidative stress related proteins including gluthatione-strnasferase, germin-like protein, quinine reductase previously reported as $\mathrm{Al}$ responsive $[15,18,19]$ showed differential expression between PI 416937 and Young at $2 \mathrm{~h}$ (Table 1). Gluthathione-s-transferase (GST) was down-regulated, whereas, the other two were up-regulated. GST is a key oxidative stress responsive gene and its low expression level in PI 416937 indicates that this genotype might not undergo server oxidative stress as the sensitive genotype. This finding is in agreement with the observations of $[9,10]$ that less Al enters PI 416937 roots compared to Young. Over-expression of GST in Arabidopsis has been shown to conferred Al tolerance [32]. However, the current consensus is that oxidative stress gene expression is more of a manifestation of $\mathrm{Al}$ toxicity rather than a tolerance mechanism $[16,33]$. A gene for isoflavone biosynthesis malonyl-COA: isoflavone 7-O-glucoside-6"-O- malontransefrase (Gma.7535) was up-regulated 17.96 and 54.65 fold at 2 , and $72 \mathrm{~h}$ respectively. Flavonoids can neutralize Al toxicity by chelating $\mathrm{Al}$ ion in vivo or in vitro [1] and/or by acting as antioxidant [18]. Several pathogenesis related proteins, thaumatin protein, cysteine protease inhibitor, xyloglycan specific fungus endoglycananse inhibitor, pathogenesis related protein, disease resistance protein, and chitinase were expressed at higher level in PI 416937 than in Young (Table 1, Additional files 1, 2\&3). The role of pathogenesis related proteins in Al tolerance is equivocal. In one study [32] over-expressed peroxidase and proteinase inhibitor genes in Arabidopsis and found that transgenic plants did not show better Al tolerance level than controls. On the other hand [34], over-expressed pepper basic pathogenesis related protein 1 gene in tobacco and found enhanced tolerance to the heavy metal cadmium and pathogen infection. Desiccation related protein, heat shock protein, and chaperonin protein were also differentially expressed between PI 416937 and Young. Late embroyogenesis abundant (LEAS) desiccation tolerance gene (Gma.15) was expressed 4.02 fold higher in P I 416937 than in Young at $2 \mathrm{~h}$ (Table 1). This is consistent with the fact that PI 416937 is both drought and Al tolerant [10]. DNAJ heat shock protein previously reported to be $\mathrm{Al}$ induced at protein level in Al tolerant soybean genotype [35] was up-regulated 5.32 and 6.45 fold at $48 \mathrm{~h}$ and $72 \mathrm{~h}$, respectively (Additional files 2, 3). A chaperonin protein (Gma.26538) was ex- pressed at 6.67 fold lower in PI $42693712 \mathrm{~h}$ post treatment (Additional file 1).

\subsubsection{Genes Related to Metabolism}

Plants undergo change in cellular metabolism upon exposure to $\mathrm{Al}$ either as a manifestation of $\mathrm{Al}$ toxicity or as a mechanism of $\mathrm{Al}$ tolerance $[15,18]$. Aluminum interferes with nutrient uptake, transportation and utilization [36]. Phosphorus deficiency due to Al-phosphate precipitation in rhizosphere, cell wall or in symplast [37] combined with $\mathrm{Al}$ induced mitochondrial dysfunction depletes ATP and other nucleoside phosphates [30]. Probably as a mechanism for increasing cellular orthophosphate supply under Al stress, a phosphorylase 4 (Gma.5609) gene was expressed at 4.91,6.61, and 5.23 fold higher in PI 416937 than in Young at 246 12, 48 and $72 \mathrm{~h}$ respectively (Additional files $1,2 \& 3$ ). The expression of this gene was 4.66 fold lower in PI 416937 than in Young at $2 \mathrm{~h}$ (Table 1). A cellulose synthase like-3 gene (Gma.13640) involved in cellulose synthesis was expressed at 7.89 and 6.15 fold lower in PI 416937 than in Young at $2 \mathrm{~h}$ and $12 \mathrm{~h}$, respectively (Table 1 and additional file 1). Cell wall polysaccharides level is inversely related to plant $\mathrm{Al}$ tolerance $[33,38]$. The lower cellulose synthase activity in PI 416937 could be an indication of $\mathrm{Al}$ tolerance mechanism. Cell wall metabolism enzymes have been suggested to alleviate $\mathrm{Al}$ induced root growth inhibition by remodeling cell wall architecture $[3,18]$. Pursuant with this, a gene for beta-xylosidase (Gma. 36991) involved in hydrolysis of O-glycoysl compounds was expressed 5.03 fold higher in PI 416937 at 2 h (Table 1). Furthermore, another gene coding for glycoysl hydrolase family3 protein (AW75634) was expressed constitutively at 4.60 fold higher in PI 416937 (Additional file 1). A pectinestrase gene (Gma.22124) was up-regulated at $12 \mathrm{~h}$ (Additional file 1). Pectinestrease activity has been shown to correlate with increase in $\mathrm{Al}$ sensitivity due to demethylation of pectin by the enzyme and increase in its $\mathrm{Al}$ adsorption capacity [3]. It is worth noting that a gene for pectin methylesetrase inhibitor family protein (Gma.31645) was up- regulated at $72 \mathrm{~h}$ (Additional file 3) probably deactivating pectinestrease, thus conferring $\mathrm{Al}$ tolerance via the exclusion mechanism.

Many eukaryotic proteins are anchored to plasma membrane by glycosyl phosphatidylinositol (GPI) [39]. $G P I$ transamidase is an endoplasmic reticulum localized protein that transfers performed GPI to proteins with GPI attachment signal in the carboxyl terminal. Aluminum tolerance genes such as organic acid ion and ATP binding cassette $(A B C)$ transporters are membrane proteins. GPI transamidase was strongly induced in the present work. It was constitutively expressed at 35.17 , 
41.82 and 51.79 fold higher at $12 \mathrm{~h}, 48$ and $72 \mathrm{~h}$ respectively in PI 416937(Additional files 1, 2\&3). Two other enzymes involved in posttranslational modification of proteins, signal peptidases, showed difference in expression level between the two genotypes. One of them Gma.2057 was down regulate at $12 \mathrm{~h}$ (Additional file 1), whereas, Gma.22290 was constitutively expressed in PI 416937 at higher level at $48 \mathrm{~h}$ (Additional file 2). Some authors [19] observed up-regulation of peptidases in Arabidopsis under Al stress. Impaired sucrose induction1 gene (Gma.4033) was expressed at 4.95 and 4.27 fold higher at 12 and $48 \mathrm{~h}$ respectively, in PI 416937 (Additional files 1\&2). Impaired sucrose induction1 encodes a conserved plant-specific protein that couples carbohydrate availability to gene expression and plant growth [40]. Mutants of this gene do not utilize carbohydrate resources efficiently. Since aluminum causes energy shortage the up- regulation of these genes in $\mathrm{Al}$ tolerant PI 416937 suggests an efficient utilization of the available carbohydrate under Al stress. A gene for polyamine-sperm dine biosynthesis (Gma.21460) was up-regulated 4.26 fold at $12 \mathrm{~h}$ (Additional file 1). Polyamines are essential for cell differentiation and growth and in plant $\mathrm{Al}$ stress tolerance [41]. Exogenous application of polyamines to $\mathrm{Al}$ containing solution culture by [41] showed enhanced Al tolerance in Crocus sativus $L$. They ascribed the amelioration of Al toxicity to exclusion of Al from entering plant roots. On the other hand [42] observed root growth inhibition in rice due to extreme accumulation of putrescine type polyamine in roots under Al stress. These studies suggest that the exact role of polyamines in $\mathrm{Al}$ tolerance may be species specific and that exact role remains largely unknown. Genes encoding UDP-glycosyl transferases Gma.6457 and Gma.30046 at $12 \mathrm{~h}$ (Additional file 1), Gma.6457 and Gma.2213 at $48 \mathrm{~h}$ (Additional file 2), and Gma.30046 and Gma.2213 at 72 h 290 (Additional file 3) were expressed at high level in PI 416937. UDP-glycolsyl transferases that glucoyslate plant secondary metabolites and hormones have been shown to be triggered by wounding, pathogen infection, and oxidative stress [43]. The glycosylation reaction converts secondary metabolites and hormones to inactive form for storage in vacuole or plastids that become available as needed. Glycosylation of low molecular weight molecules like harmful metabolites or environmental compounds also allow the solubilization of these compounds in water for detoxification and modulation of their biological activity [43]. Biosynthesis and homeostasis of secondary metabolites with antioxidant and detoxification property such polyphenols, benzoic acid and terpeniods could relate these enzymes to $\mathrm{Al}$ tolerance.

\subsubsection{Cell Signaling, Structural and Cell Cycle Genes}

Like other environmental or endogenous signals, perception and transmission of $\mathrm{Al}$ by the cell constitutes the initial steps of plant response to Al toxicity. Protein kinases and phosphatases which activate proteins by phosphorylation and dephosphorylation, respectively, are the key players in cell signaling. Cell wall associated receptor kinase (WAK1) is the first of such genes identified to be involved in Al signaling [44]. In our study, a protein kinase family gene Gma.2166 was up-regulated 7.88 fold at $2 \mathrm{~h}$ (Table 1). A second protein kinase family gene BI317550 was down-regulated 8 fold at $12 \mathrm{~h}$ (Additional file 1) and up-regulated 7.18 fold at $48 \mathrm{~h}$ (Additional file 2). Protien kinases activate proteins by phosphorylating serine/theorine residues of target proteins. Protein phosphatase $2 \mathrm{c}$ that activates target signaling proteins by opposite action of dephosphorylation was also up-regulated 4.54 and 5.43 fold at 12 and $72 \mathrm{~h}$ respectively (Additional file 1\&2). Two other kinases, wall associated kinase Gma.27299 (Additional file 1) and transmembrane receptor kinases Gma.39148 (Additional file 2) were down-regulated. In Arabidobsis [19] identified several aluminum responsive protein kinases and phosphatases similar to the ones reported in our study. It worths noting that a novel cell cycle gene, encoding WPP2 domain protein found to be involved in mitosis and tap root elongation and lateral root proliferation [45] was constitutively expressed at $6.42,9.25$, 12.25 and 10.94 fold higher in PI 416139 at 2, 12, 48 and $72 \mathrm{~h}$ respectively (Table 1, Additional files 1, 2\&3). The main mechanism of $\mathrm{Al}$ induced root growth inhibition occurs by hindrance of cell division and cell elongation. We postulate that the higher expression level of cell division stimulating and lateral root proliferation gene in PI 416937 may partly contribute to its Al and drought tolerance characteristics. Histone H1-3 DNA binding protein (Gma.5833) was constitutively and consistently up-regulated 10.27, 8.37, and 12.56 fold at 12,48 and 72 $\mathrm{h}$ respectively (Additional files 1, 2\&3). Histone proteins are required for nucleosome assembly and their induction under Al stress was previously reported in Arabidopsis [18]. A lipid sequestration oleosin protein (Gma.17961) and octicosapeptide PB1 domain protein with signaling function were up-regulated at $2 \mathrm{~h}$. Oleosin protein has been recently shown by mutation analysis to be involved in cold tolerance in oilseeds of Arabidopsis [46].

\section{CONCLUSIONS}

We compared the transcriptome profiles of Al-tolerant and Al-sensitive soybean genotypes to identify potential genetic factors underlying $\mathrm{Al}$ tolerance trait. Our results 
uncovered several novel putative genes which might potentially have influence on soybean Al tolerance. Among these are, rare cold inducible protein (RCI2B), a cell proliferation protein (WPP2), pectinestrease inhibitor, ADR6-like transcription factor, oleosin protein and malonyl-COA: Isoflavone 7-O-glucoside-6"-O-malontransferase. The transcription factor, ADR6 is an auxin down regulated gene. Al suppresses auxin biosynthesis and transport in root system which might be one possible mechanism of $\mathrm{Al}$ induced root growth inhibition. Conversely, $A D R 6$ is triggered under Al stress probably acting in parallel pathway to auxin to restore root growth under Al stress. Root cell wall rigidification by Al binding is one principal mechanism of $\mathrm{Al}$ toxicity. Cell wall metabolism enzymes and proteins are induced under $\mathrm{Al}$ stress and may counteract $\mathrm{Al}$ effects on root cell walls. It is increasingly evident that these proteins as well as cell wall pectin and hemicelluloses contents are important determinants of Al tolerance. Evidence from this study implies that cell wall remodeling enzymes and proteins may play role in soybean Al tolerance. In conclusion, as judged by levels and patterns of expression difference between tolerant and sensitive genotypes, cellular function, and mechanisms of aluminum tolerance and toxicity some of the genes described in this study could be the genetic determinants of Al-tolerance trait in soybean. These genes deserve further functional characterization for eventual utilization in developing soybean germplasm adapted to high aluminum soils.

\section{ACKNOWLEDGEMENTS}

We are grateful to USDA Plant Genetic Resources and Dr. Thomas Carter of North Carolina State University for generous gifts of the seeds of soybean genotypes used in this study. We thank Dr. Ernie Cebert of Alabama A\&M University for his kind assistance in seed multiplication. We are indebted to Dr. Michael Crowley, Genomics Core facility at University of Alabama at Birmingham for his assistance and training on microarray analysis in this project. This research was supported in part by NSF/EPSCOR grant no. 05026. The financial support of Alabama Graduate Research Scholars Program is greatly appreciated.

\section{REFERENCES}

[1] Kochian, L.V, Hoekenga, O.A. and Piñeros, M.A. (2004) How do crop plants tolerate acid soils? Mechanism of aluminum tolerance and phosphorous efficiency. Annual Review of Plant Biology, 55, 459-493.

doi:10.1146/annurev.arplant.55.031903.141655

[2] Ma, J.F., Ryan, P.R. and Delhaize, E. (2001) Aluminum tolerance in plants and the complexing role of organic acids. Trends in Plant Science, 6, 273-278.

doi:10.1016/S1360-1385(01)01961-6
[3] Eticha, D., Staß, A. and Horst, W.J. (2005) Localization of aluminum in the maize root apex: Canmorin detect cell wall-bound aluminum. Journal of Experimental Botany, 56, 1351-1357. doi:10.1093/jxb/eri136

[4] Hossain, Z.A.K., Koyama, H. and Hara, T. (2006) Growth and cell wall properties of two wheat cultivars differing in their sensitivity to aluminum stress. Journal of Plant Physiology, 163, 39-47. doi:10.1016/j.jplph.2005.02.008

[5] Mortia, A., Yanagisawa, O., Takatsu, S., Maeda, S. and Hiradate, S. (2008) Mechanism for the detoxification of aluminum in roots of tea plant (Camellia sinsensis (L) Kuntze). Phytochemistry, 69, 147-153.

doi:10.1016/j.phytochem.2007.06.007

[6] Watanabe, T., Osaki, M., Yano, H. and Rao, I.M. (2006) Internal mechanisms of plant adaptation to aluminum toxicity and phosphorus starvation in three tropical forages. Journal of Plant Nutrition, 29, 1243-1255. doi:10.1080/01904160600767484

[7] Sasaki, T., Yamamoto, Y., Ezaki, B., Katsuhara, M., Ahn, S.J., Ryan, P.R., Delhaize, E. and Matsumoto, H.A. (2004) Wheat gene encoding aluminum activated malate transporter. The Plant Journal, 37, 645-653. doi:10.1111/j.1365-313X.2003.01991.x

[8] Magalhaes, J.V., Liu, J., Guimará, C.T., Lana, U.G.P, Alves, V.M.C., Wang, Y.H., Schaffert, R.E., Hoekenga, O.A., Piñehaff, M.A., klein, P.E., Carneiro, N.P., Coelho, C.M., Trick, H.N. and Kochian, L.V.(2007) A gene in the multidrug and toxic compound extrusion (MATE) family confers aluminum tolerance in sorghum. Nature Genetics, 39, 1156-1161. doi:10.1038/ng2074

[9] Silva, I.R., Smyth, T.J., Israel, D.W., Raper, C.D., Ruffy, T.W. (2001) Magnesium is more efficient than calcium in alleviating aluminum rhizotoxicity in soybean and its ameliorative effect is not explained by the gouy-chapman-stern model. Plant Cell Physiology, 42, 538-545. doi:10.1093/pcp/pce066

[10] Bianchi-Hall, C.M., Carter, T.E., Bailey, M.A., Mian, M.A.R., Ashley, D.A., Boerma, H,E., Arellano C, Hussey, R.S. and Parrott, W.A. (2000) Aluminum tolerance associated with quantitative trait loci derived from soybean PI 416937 in hydroponics. Crop Science, 40, 538-545. doi:10.2135/cropsci2000.402538x

[11] Nian, H., Yang, Z., Huang, H. and Yan, X. (2004) Citrate secretion induced by aluminum stress may not be a key mechanism responsible for differential aluminum tolerance of some soybean genotypes. Journal of Plant Nutrition, 27, 2047-2066. doi:10.1081/PLN-200030112

[12] Ermolayev, V., Weschke, W. and Manteuffel, R. (2003) Comparison of Al-induced gene expression in sensitive and tolerant soybean cultivars. Journal of Experimental Botany, 54, 2745-2756. doi:10.1093/jxb/erg302

[13] Ragland, M. and Soliman, K.M. (1997) Two genes induced by $\mathrm{Al}$ in soybean roots. Plant Physiology, 114, 395.

[14] Guo, P., Bai, G., Carver, B., and Li, R. (2007) Transcriptional analysis between two wheat near-isogeniclines contrasting in aluminum tolerance under aluminum stress. Mol Genet Genomics, 277, 1-12. doi:10.1007/s00438-006-0169-x

[15] Hounde, M. and Diallo, A.O. (2008) Identification of genes and pathways associated with aluminum stress and 
tolerance using transcriptome profiling of wheat nearisogenic lines. BMC Genomics, 9, 400. doi:10.1186/1471-2164-9-400

[16] Maron, L.G., Kirst, M., Mao, C., Milner, M.J., Menossi, M. and Kochian L.V. (2008) Transcriptional profiling of aluminum toxicity and tolerance responses in maize roots. New Phytologist, 179, 116-128. doi:10.1111/j.1469-8137.2008.02440.x

[17] Chandran, D., Sharopova, N., Ivashuta, S., Gantt, J.S., VandenBosch, K.A. and Samac, D.A. (2008a) Transcriptome profiling identified novel genes associated with aluminum toxicity, resistance and tolerance in Medicago truncatula. Planta, 228, 151-166. doi:10.1007/s00425-008-0726-0

[18] Chandran, D., Sharopov, N., VandenBosch, K.A., Garvin, D.V. and Samac, D.A. (2008b) Physiological and molecular characterization of aluminum resistance in Medicago truncatula. BMC Plant Biology, 8, 89. doi:10.1186/1471-2229-8-89

[19] Kumari, M., Taylor, G.J. and Deyholos, M.K. (2008) Transcriptome responses to aluminum stress in roots of Arabidopsis. Mol Genet Genomics, 279, 339-357. doi:10.1007/s00438-007-0316-Z

[20] Furukawa, J., Yamaji, N., Wang, H., Mitan, N., Murata, Y., Sato, K., Katsuhara, M., Takeda, K. and Ma, J.F. (2007) An aluminum activated citrate transporter in barley. Plant cell Physiology, 48, 1081-1091. doi:10.1093/pcp/pcm091

[21] Wu, Z., Soliman, K.M., Bolton, J.J., Saha, S. and Jenkins, J.N. (2008) Identification of differentially expressed genes associated with cotton fiber development in a chromosomal substitution line (CS-B22sh). Funct Integr Genomics, 8, 165-174. doi:10.1007/s10142-007-0064-5

[22] Morey, J.S., Ryan, J.C. and Van Dolah, F.M. (2006) Microarray validation factors influencing correlation between oligonucleotide microarrays and real-time PCR. Biology Proceeding online, 8, 175-193.

[23] Zhu, J., Shi, H., Lee, B.H., Damsz, B., Cheng, S., Stirm, V. and Zhu, J.K. (2004) An arabidopsis homeodomain transcription factor gene, HOS9, mediates cold tolerance through a CBF-independent pathway. Proceedings of the National Academy of Sciences of the United States of America, 101, 9873-9878. doi:10.1073/pnas.0403166101

[24] Udvardi, M.K., Kakar, K., Wandrey, M, Montanari, O., Murray, J., Andriankaja, A., Zhang, J.Y., Benedito, V., Hofer, J.M.I., Chueng, F. and Town, C.D. (2007) Legume transcription factors: Global regulators of plant development and response to the environment. Plant Physiology, 144, 538-549. doi:10.1104/pp.107.098061

[25] Zhang, Y., Wang, Z., Zhang, L., Cao, Y., Huang, D. and Tang, K. (2006) Molecular cloningand stress-dependent regulation of potassium channel gene in Chinese cabbage (Brassica rapa asp. Pekinensis).Plant Physiology, 163, 968-978. doi:10.1016/i.jplph.2005.09.002

[26] Kader, J.C. (1997) Lipid transfer proteins: a puzzling family of plant proteins. Trends in Plant Science, 2, 66-70. doi:10.1016/S1360-1385(97)82565-4

[27] Nieuwald, J., Feron,.R., Huisman, B.A.H., Fasolino, A., Hilbers, C.W., Derksen, J. and Marian, C. (2009) Lipid transfer proteins enhance cell wall extension in tobacco. The Plant Cell 2005, 17, 2009-2019.

[28] Rengel, Z. and Zhang, W.H. (2003) Role of dynamics of intracellular calcium in aluminum toxicity syndrome. New Physiologist, 159, 295. doi:10.1046/j.1469-8137.2003.00821.x

[29] Williams, L.E., Lemoine, R. and Sauer, N. (2000) Sugar transporters in higher plants-a diversity of roles and complex regulation. Trends in Plant Science, 5, 283-290. doi:10.1016/S1360-1385(00)01681-2

[30] Yamamoto, Y., Kobayashi, Y., Devi, S.R., Rikiishi, S. and Matsumoto, H. (2002) Aluminum toxicity is associated with mitochondrial dysfunction and the production of reactive oxygen species in plant cells. Plant Physiology, 128, 63-72. doi:10.1104/pp.010417

[31] Llorenta, F., Cobollo, R.M.L., Catalá, R., Zapater, J.M. and Salinas, J. (2002) A novel cold-inducible gene from Arabidopsis, RCI3, encodes a peroxidase that constitutes a component for stress tolerance. The Plant Journal, 32, 13-24. doi:10.1046/j.1365-313X.2002.01398.x

[32] Ezaki, B., Gardner, R.C., Ezaki, Y. and Matsumoto, H. (2000) Expression of aluminum-induced genes in transgenic arabidopsis plants can ameliorate aluminum stress and/or oxidative stress. Plant Physiology, 127, 918-927. doi:10.1104/pp.010399

[33] Liu, Q., Yang, J.L., He, L.S., Li, Y.Y. and Zheng, S.J (2008) Effect of aluminum on cell wall, plasma 555 membrane, antioxidants and root elongation in triticale. Biologica Planttarum, 2, 87-92. doi:10.1007/s10535-008-0014-7

[34] Sarowar, S., Kim, Y.J., Kim, E.N., Kim, K.D., Hwang, B.K.H., Islam, R. and Shin, J.S. (2005) Over expression of a pepper basic pathogenesis-related protein 1 gene in tobacco plants enhances resistance to 559 heavy metal and pathogen stresses. Plant Cell Report, 24, 216-224. doi:10.1007/s00299-005-0928-x

[35] Zhen, Y., Qi, J.L., Wang, S.S., Su, J., Xu, G.H., Zhang, M.S. and Miao, L.V. (2007) Comparative proteome analysis of differentially expressed proteins induced by Al toxicity in soybean. Physiologia Plantrarum, 131, 542-554. doi:10.1111/j.1399-3054.2007.00979.x

[36] Rout, G.R. and Samantaray, S. (2001) Aluminum toxicity in plants: A review. Agronomie, 21, 3-21. doi:10.1051/agro:2001105

[37] Jemo, M., Abaidoo, R.C., Nolte, C. and Johannes, W. (2006) Aluminum resistance of cowpea as affected by phosphorus-deficiency stress. Journal of Plant Physiology, 164, 442-451.doi:10.1016/j.jplph.2005.12.010

[38] Yang, J.L., Zhang, L.Y., Zhang, Y.J., Wu, S.S., Wu, Y.R. and Zheng, P. (2008) Cell wall polysaccharides are specifically involved in the exclusion of aluminum from the rice root apex. Plant Physiology, 146, 602-611. doi:10.1104/pp.107.111989

[39] Ohishi, K., Nagamune, K., Maeda, Y. and Kinoshita, T. (2003) Two subunits of GPI transamidase GPI8 and PIG-T form a functionally important intermolecular disulfide bridge. Journal of Biochemistry, 16, 13959-13967.

[40] Rook, F., Corke, F., Baier, M., Holman, R., May, A.G. and Bevan, M.W. (2006) Impaired sucrose induction1 encodes a conserved plant-specific protein that couples carbohydrate availability to gene expression and plant growth. Plant Journal, 46, 1045-1058. doi:10.1111/j.1365-313X.2006.02765.X

[41] Chen, W., Xu, C., Zhao, E.B., Wang, E.X. and Wang, E.Y. (2008) Improved Al tolerance of saffron (Crocus sativus 
L.) by exogenous polyamines. Acta Physiology Plant, 30, 121-127. doi:10.1007/s11738-007-0100-z

[42] Wang, J.W. and Kao, C.H. (2006) Aluminum inhibited root growth of rice seedlings is mediated through putresciene accumulation. Plant Soil, 288, 373-381. doi:10.1007/s11104-006-9127-y

[43] Sepu, G., Jime,.I., Ben1, P.R., Porta, H. and Sosa, M.R. (2005) A red beet (Beta vulgaris) UDP-glucosyltranferase gene induced by wounding, bacterial infiltration and oxidative stress. Journal of Experimental Botany, 56, 605-611. doi:10.1093/jxb/eri036

[44] Sivaguru, M., Ezaki, B., He, Z.H.,Tong, H., Osawa, H., Baluska, F.,Volkmann, F. and Matsumoto, H. (2003) Aluminum induced gene expression and protein localization of a cell wall-associated receptor kinase in arabidopsis. Plant Physiology, 32, 2256-2266. doi:10.1104/pp.103.022129

[45] Patel, S., Rose, A., Meulia, T., Dixit, R., Richard, J.C. and Meiera, I. (2004) Arabidopsis WPP-domain proteins are developmentally associated with the nuclear envelope and promote cell division. The Plant Cell, 16, 3260-3273. doi: $10.1105 /$ tpc. 104.026740

[46] Shimada, T. (2000) Oilseeds in arabidopsis thalina. The Plant Journal, 55, 798-809. doi:10.1111/i.1365-313X.2008.03553.x

[47] Silva, I.R., Smyth, T.J., Moxley, D.F., Carter, T.E., Allen, N.S. and Ruffy, T.W. (2000) Aluminum accumulation at the nuclei of cells in the root tip. fluorescence detection using lumogallion and confocal laser scanning microscopy. Plant Physiology, 23, 543-552. doi:10.1104/pp.123.2.543

[48] Wu, Z., Irizarry, A.R., Gentleman, R., Murillo, F.M. and Spencer, F. (2004) A model-based background adjustment for oligonucleotide expression arrays. Journal of the American Statistical Association, 99, 909. doi:10.1198/016214504000000683

[49] Pfaffi, M.W. (2001) A new mathematical model for relative quantification in real time RT- PCR. Nucleic Acids Research, 29, 2002-2007.

\section{Additional materials}

Additional file 1 Table of genes differential expressed between Al-tolerant PI 416937 and Al-sensitive Young $12 \mathrm{~h}$ post aluminum treatment

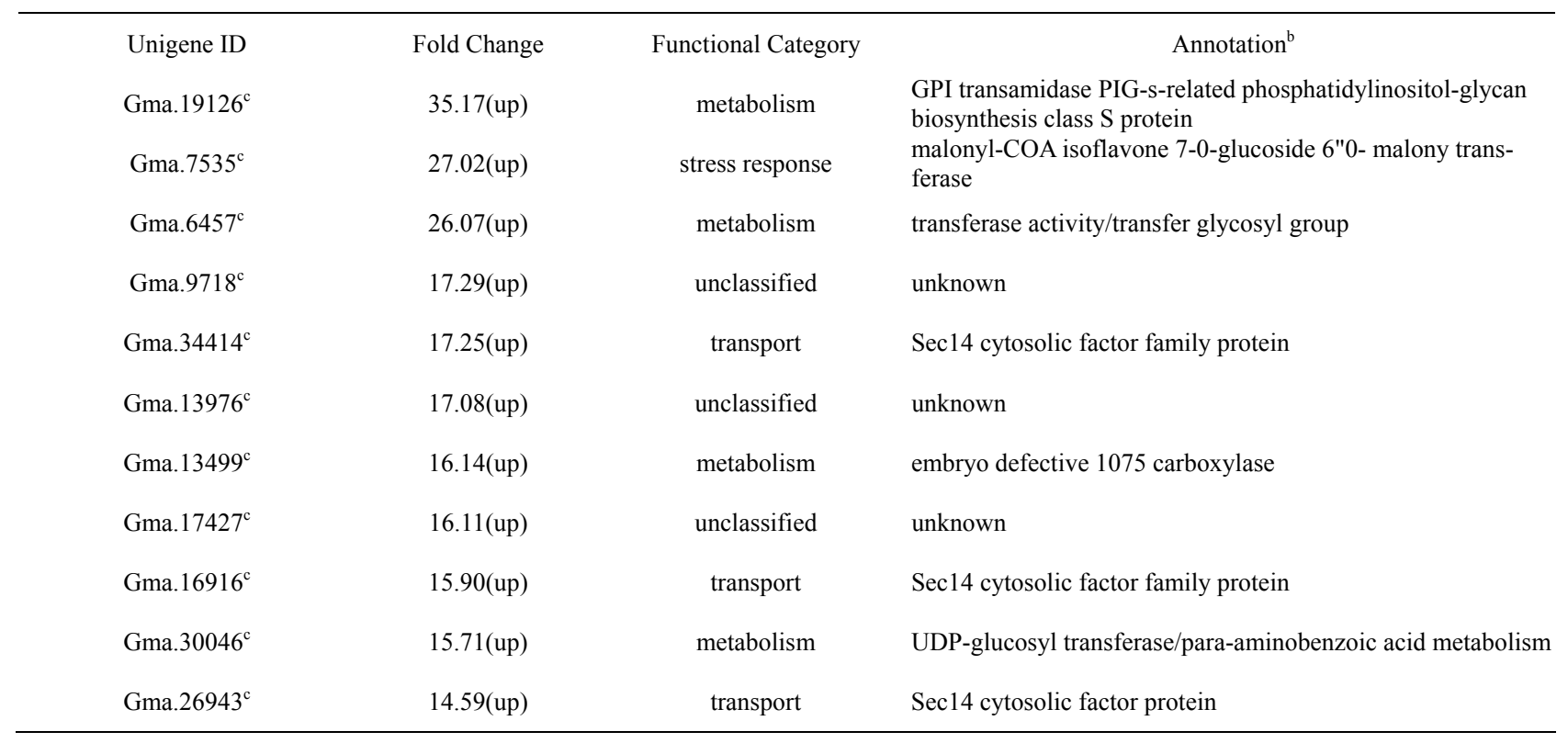




\begin{tabular}{|c|c|c|c|}
\hline Gma. $8198^{c}$ & 14.08(up) & unclassified & hypothetical protein \\
\hline Gma.25191 & 12.02(down) & unclassified & unknown \\
\hline Gma. $17162^{c}$ & 11.68(up) & unclassified & hypothetical protein \\
\hline Gma. $21642^{c}$ & $11.27($ down $)$ & unclassified & unknown \\
\hline Gma. $30710^{\mathrm{c}}$ & 10.40 (up) & transport & Sec 14 cytosolic factor family protein \\
\hline Gma.2057 & 10.14(down) & metabolism & Signal peptidase/proteolysis \\
\hline Gma. $5833^{\mathrm{c}}$ & 10.27(up) & structural & histone1-3 DNA binding \\
\hline Gma.27299 & 10.14(down) & cell signaling & WAK5/wall associated kinase, kinase activity \\
\hline Gma.4281 & 9.94(down) & transcription factor & WRKY70 DNA binding protein transcription factor \\
\hline Gma. $2213^{\mathrm{c}}$ & 9.54(up) & metabolism & $\begin{array}{l}\text { UDP-glucoronosyl/transfers glycosyl group } \\
\text { Para-amino benzoic acid biosynthesis process }\end{array}$ \\
\hline Gma.395 & 9.25 (up) & cell cycle & WPP2 domain protein1/lateral root development \\
\hline Gma. $3880^{\mathrm{c}}$ & 9.15 (up) & transport & lipid transfer protein-related/lipid binding/lipid transfer \\
\hline Gma. $21421^{\mathrm{c}}$ & 9.0 (up) & unclassified & hypothetical protein \\
\hline Gma. $21625^{\mathrm{c}}$ & 8.92(down) & unclassified & unknown \\
\hline Gma. $22330^{\mathrm{c}}$ & 8.12 (up) & unclassified & unknown \\
\hline $\mathrm{BI} 317550^{\mathrm{c}}$ & 8.00(down) & signaling & protein kinase family protein/kinase activity \\
\hline Gma. $15692^{c}$ & 7.95(down) & unclassified & unknown \\
\hline Gma. $33997^{\mathrm{c}}$ & 7.62(down) & & Ran GTpase/chromatin binding, zinc ion binding \\
\hline Gma. $21391^{\mathrm{c}}$ & 7.30(up) & unclassified & unknown \\
\hline $\mathrm{BI} 788325^{\mathrm{c}}$ & 7.26(down) & unclassified & unknown \\
\hline Gma.4819 & 7.09(up) & unclassified & hypothetical protein \\
\hline Gma. $10737^{\mathrm{c}}$ & $6.98($ down $)$ & unclassified & hypothetical protein \\
\hline Gma. $22290^{c}$ & 6.73(up) & metabolism & serine carboxypeptidase/proteolysis \\
\hline Gma. $24523^{\mathrm{c}}$ & $6.68($ down $)$ & metabolism & dehydrodolichyl diphosphate synthase/ dolichol biosynthesis \\
\hline Gma. $26538^{\mathrm{c}}$ & $6.67($ down $)$ & stress response & chaperonin putative \\
\hline BU551389 & $6.64($ down $)$ & metabolism & reverse transcriptase \\
\hline Gma.36363 & 6.59 (up) & metabolism & UDP-glucosyl transferase \\
\hline Gma.33184 & 6.54(up) & stress response & Xyloglucan specific fungus endoglucanase inhibitor \\
\hline Gma. $9683^{\mathrm{c}}$ & 6.53(up) & unclassified & unknown \\
\hline Gma.8292 & 6.19 (up) & stress response & functional resistance protein $\mathrm{KR} 1$ \\
\hline Gma. $13640^{c}$ & $6.15($ down $)$ & metabolism & cellulose synthase-like A3/cellulose synthase \\
\hline Gma.10407c & 6.02 (up) & metabolism & phospholipid diacylglycerol acyltransferase lipid metabolism \\
\hline Gma.6707c & $6.01($ down $)$ & transport & dicarboxylate/tricarboxylate carrier/mitochondrial transport \\
\hline Gma.2256c & 5.96(down) & structural & ribosomal protein $\mathrm{P} 2 / 60 \mathrm{~S}$ acidic ribosomal protein \\
\hline
\end{tabular}




\begin{tabular}{|c|c|c|c|}
\hline BI971552c & 5.82 (up) & unclassified & hypothetical protein \\
\hline Gma.22124 & 5.70 (up) & metabolism & pectinestrase family protein/cell wall modification \\
\hline Gma.10907 & 5.58(up) & unclassified & hypothetical protein \\
\hline Gma.10858c & 5.33 (down) & cell signaling & $\begin{array}{l}\text { jasmonate-z-domain protein3/ jasmonic acid mediated } \\
\text { signaling }\end{array}$ \\
\hline Gma.6245c & 5.28(up) & stress response & pathogenesis related thaumatin protein family \\
\hline Gma.22107c & 5.24(up) & metabolism & hydrolase homolo6 ADP-ribose diphosphatase \\
\hline BI316842 c & 5.15 (up) & unclassified & unknown \\
\hline Gma.5622 & 5.06 (down) & unclassified & unknown \\
\hline Gma.4033c & 4.95(up) & metabolism & $\begin{array}{l}\text { impaired sucrose induction } 1 / \text { controls growth and } \\
\text { Development }\end{array}$ \\
\hline Gma.14036c & 4.92(down) & unclassified & unknown \\
\hline Gma.5609c & 4.91(up) & metabolism & pyrophosphorylase4/ inorganic diphosphatase activity \\
\hline Gma.37580c & 4.75(up) & transport & sulfate transmembrane transporter \\
\hline Gma. $15804 \mathrm{c}$ & 4.82(down) & unclassified & hypothetical protein \\
\hline Gma.16666c & 4.78(down) & transcription factor & basic helix-loop-helix family protein/transcription factor \\
\hline Gma.510616c & 4.71(up) & unclassified & unknown \\
\hline Gma.15007c & 4.64(up) & metabolism & iron-sulfur cluster binding protein/electron transfer \\
\hline AW756534c & 4.60(up) & metabolism & glycosyl hydrolase family 3 protein/o-glycosyl cpds \\
\hline Gma.24361c & 4.54(up) & signaling & protein phosphotase $2 \mathrm{c} /$ phosphatase activity \\
\hline Gma.22442c & 4.53(down) & unclassified & unknown \\
\hline Gma.17931c & 4.47 (down) & metabolism & choloroplast thylakoid processing peptidase \\
\hline Gma.13006c & 4.47(up) & unclassified & hypothetical protein \\
\hline Gma.2848c & 4.35(up) & cell cycle & $\begin{array}{l}\text { ribonucleotide-diphosphate reductase /DNA repair cell cycle } \\
\text { regul. }\end{array}$ \\
\hline Gma.39148 & 4.34(down) & signaling & receptor kinase/transmembrane receptor protein \\
\hline Gma.21460c & 4.26(up) & metabolism & SPDS1 spermidine synthase activity/spermidine biosynthesis \\
\hline Gma.1288c & 4.18(up) & unclassified & unknown \\
\hline Gma.24428 & 4.15(up) & unclassified & unknown \\
\hline Gma.22248c & 4.13(down) & structural & myosin-like protein/actin filament based movement \\
\hline Gma.4958 & 4.13(down) & metabolism & acyl-activating enzyme $12 /$ catalytic activity metabolic process \\
\hline Gma.17205c & 4.13(up) & transport & $\begin{array}{l}\text { zinc induced facilitator-like1 carbohydrate transmembrane } \\
\text { transporter activity }\end{array}$ \\
\hline Gma.20904 & 4.09(up) & unclassified & hypothetical protein \\
\hline Gma.42414c & 4.06(down) & transport & ATCAx6 calcium exchanger/calcium: cation antiporter activity \\
\hline Gma.17306c & 4.05(up) & structural & structural molecule/ cell adhension \\
\hline Gma.20157 & 4.03(up) & metabolism & $\begin{array}{l}\text { UDP-Gl cNAc dolichol phosphate N-acylglucosamine } \\
\text { Transferase }\end{array}$ \\
\hline
\end{tabular}

a significance thresholds (fold change $\geq 4, \mathrm{p} \leq 0.01)$, b e-value $(<\mathrm{e}-10)=$ the probability that the match has no biological basis, cconstitutively expressed, dup=up-regulated in PI 416937 relative to Young, down=down-regulated in PI 416937 relative to Young. Note: constitutively expressed means the gene is expressed at higher or lower level in PI 416937 relative to Young with or without aluminum treatment. 
Additional file 2 Table of genes differentially expressed between Al-tolerant PI 416937 and Al-sensitive Young $48 \mathrm{~h}$ post aluminum treatment.

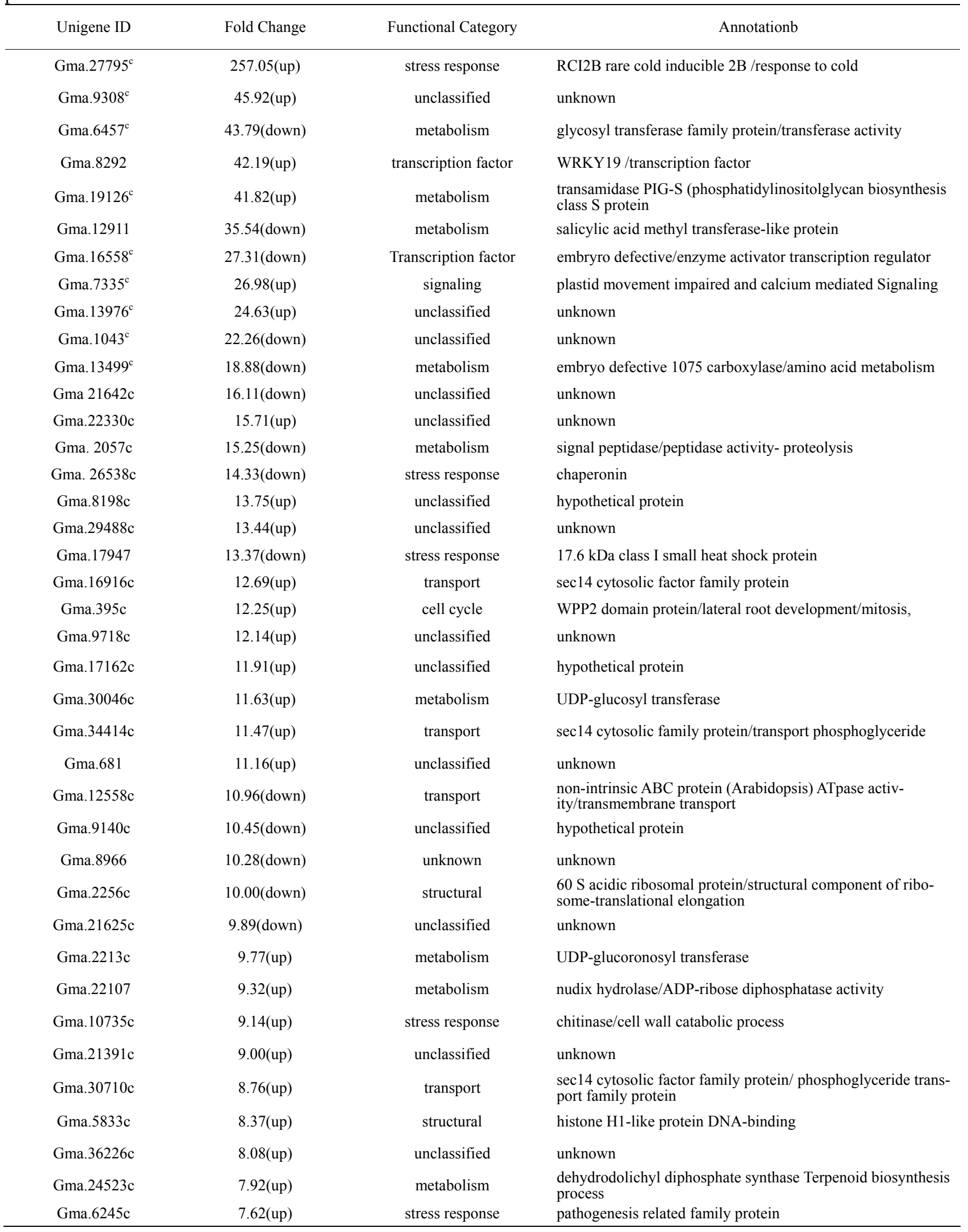




\begin{tabular}{|c|c|c|c|}
\hline BI317550c & 7.18(up) & cell signaling & family protein \\
\hline Gma.8456 & 7.08(up) & stress response & resistance protein KR2 \\
\hline Gma.9683c & 7.02(up) & unclassified & unknown \\
\hline Gma.7840c & 6.86(up) & unclassified & unknown \\
\hline Gma.3880c & 6.79 (up) & transport & lipid transfer/lipid binding-lipid transport \\
\hline Gma.6707c & 6.69 (up) & transport & $\begin{array}{l}\text { dicarboxylate/tricarboxylate carrier, binding oxidative phos- } \\
\text { phorylation /cell wall component }\end{array}$ \\
\hline Gma.1343c & 6.72(up) & unclassified & unknown \\
\hline Gma.5609c & 6.61(up) & metabolism & pyrophosphorylase/ inorganic diphosphatase metabolic process \\
\hline BI316842c & 6.25 (up) & unclassified & unknown \\
\hline Gma.6883c & 6.16 (up) & unclassified & unknown \\
\hline Gma.38915c & 6.00 (down) & structural & $\begin{array}{l}\text { Ran GTpase binding/zinc ion binding regulator of chromosome } \\
\text { condensation }\end{array}$ \\
\hline Gma.17427 & 5.98(up) & unclassified & unknown \\
\hline Gma.33146 & $5.88($ down $)$ & response to stress & glutathione-s-transferase/toxin catabolic process \\
\hline Gma.22248 & 5.83(down) & structural & myosin-like protein XIF/motor activity \\
\hline BE822969c & 5.74(up) & unclassified & unknown \\
\hline Gma.28057 & 5.68(up) & Transcription factor & ADR6 transcription factor/Sal5-4a protein \\
\hline Gma.15692c & 5.62(up) & unclassified & unknown \\
\hline Gma.24361c & 5.43(up) & signaling & protein phosphatase $2 \mathrm{c}$ \\
\hline Gma.34568c & 5.40 (up) & response to stress & disease resistance/protein binding \\
\hline Gma.1840c & 5.32(up) & Response to stress & DNAJ heat shock protein/ $\mathrm{N}$-terminal \\
\hline Gma.12898c & 5.29 (up) & unclassified & unknown \\
\hline Gma.17306c & 5.18 (up) & transcription factor & bzip (bzip94) transcription factor \\
\hline Gma.31872c & 4.94(up) & metabolism & polyubiquitin \\
\hline Gma. 413 & 4.74(up) & stress response & $\begin{array}{l}\text { peroxidase/response to oxidative stress (prx4) coumarine and } \\
\text { phenylpropanoid biosynthesis }\end{array}$ \\
\hline Gma.8417c & 4.68(up) & signaling & calmodulin-like domain protein kinase \\
\hline Gma.42414c & 4.68(down) & transport & calcium exchanger $6 /$ calcium antiporter \\
\hline Gma.9308 & 4.49(up) & unclassified & unknown \\
\hline Gma.13006c & 4.46(up) & unclassified & hypothetical protein \\
\hline Gma.33748c & 4.46(down) & stress response & glutathione-s-transferase/toxin catabolic activity \\
\hline Gma.33997c & 4.40(down) & unclassified & unknown \\
\hline Gma.17205 & 4.33(up) & transport & $\begin{array}{l}\text { zinc induced facilitator-like1/sugar: hydrogen symporter activ- } \\
\text { ity }\end{array}$ \\
\hline Gma.10961 & 4.30 (up) & unclassified & unknown \\
\hline Gma.3345 & 4.28 (up) & metabolism & class III alcohol dehydrogenase 5 metabolic process \\
\hline Gma.4033c & 4.27 (up) & metabolism & $\begin{array}{l}\text { impaired sucrose induction } 1 / \text { carbohydrate metabolism regula- } \\
\text { tion }\end{array}$ \\
\hline BI971205 & $4.25($ down $)$ & unclassified & unknown \\
\hline Gma.31872 & 4.22(down) & metabolism & polyubiquitin \\
\hline Gma.17053 & 4.21(down) & stress response & glyceraldehydes dehydrogenase/response to stress \\
\hline Gma.31645 & 4.08(up) & metabolism & invertase/pectin methyl esterase inhibitor family protein \\
\hline Gma. 22290* & 4.12(up) & metabolism & serine peptidase family like10/caboxy peptidase \\
\hline
\end{tabular}

\footnotetext{
${ }^{\mathrm{a}}$ significance thresholds (fold change $\left.\geq 4, \mathrm{p} \leq 0.01\right),{ }^{\mathrm{b}}$ e-value $(<\mathrm{e}-10)=$ the probability that the match has no biological basis, ${ }^{\mathrm{c}}$ constitutively expressed, ${ }^{\mathrm{d}}$ up=up-regulated in PI 416937 relative to Young, down=down-regulated in PI 416937 relative to Young. Note: constitutively expressed means the gene is expressed at higher or lower level in PI 416937 relative to Young with or without aluminum treatment.
} 
Additional file 3 Table of genes differentially expressed between Al-tolerant PI 416937 and Al-sensitive Young $72 \mathrm{~h}$ post aluminum treatment.

\begin{tabular}{|c|c|c|c|}
\hline Unigene ID & Fold Change & Functional Category & Annotationb \\
\hline Gma. 30979 & 8.4 & unclassified & Cab3 chlorophyll a/b binding protein \\
\hline Gma.12839 & 12.77 & unclassified & unknown \\
\hline Gma.12898c & 10.05 & unclassified & unknown \\
\hline Gma.13035 & 5.23 & unclassified & unknown \\
\hline Gma.13231 & 3.60 & structural & VAP27-2 (VAMP/SYNAPTOBREVIN 27-2 structural molecule \\
\hline Gma. $13976^{\mathrm{c}}$ & 55.61 & unclassified & unknown \\
\hline Gma.3529 & 5.31 & unclassified & unknown \\
\hline Gma. $5716^{\mathrm{c}}$ & 9.21 & unclassified & unknown \\
\hline Gma.6184 & 17.57 & unclassified & $\begin{array}{l}\text { 3-dehydroquinate dehydratase/ NADP binding embryo defective } \\
3004\end{array}$ \\
\hline Gma.681 & 6.67 & unclassified & unknown \\
\hline Gma. $7719^{\mathrm{c}}$ & 5.43 & unclassified & unknown \\
\hline Gma. $7840^{\mathrm{c}}$ & 7.07 & unclassified & unknown \\
\hline Gma.9308 & 15.23 & unclassified & unknown \\
\hline Gma. $9683^{c}$ & 6.06 & unclassified & unknown \\
\hline Gma. $9718^{\mathrm{c}}$ & 10.96 & unclassified & unknown \\
\hline Gma. $26808^{\mathrm{c}}$ & 5.08 & unclassified & hypothetical protein \\
\hline Gma. $32966^{\mathrm{c}}$ & 5.35 & metabolism & pseudouridine synthase family protein \\
\hline Gma. $21391^{\circ}$ & 8.09 & unclassified & unknown \\
\hline Gma. $1343^{\mathrm{c}}$ & 10.99 & unclassified & unknown \\
\hline Gma. $18784^{\circ}$ & 4.18 & unclassified & unknown \\
\hline Gma. $22330^{\mathrm{c}}$ & 5.67 & unclassified & unknown \\
\hline Gma.16334 & 6.59 & stress response & Uridylytransferase-related protein/response to cold \\
\hline Gma.5609 & 5.23 & metabolism & Pyrophosphorylase4 inorganic diphosphatase metabolic process \\
\hline Gma.16838 & 8.09 & metabolism & photosystem I subunit $\mathrm{H}-2$ /function photosynthesis \\
\hline Gma. $27795^{\mathrm{c}}$ & 253.35 & stress response & rare cold-inducible $2 \mathrm{~b}$ ( $\mathrm{RCI} 2 \mathrm{~b}$ ) \\
\hline Gma.15377 & 5.72 & metabolism & PSAG/photosystem I-NADP + reduction \\
\hline Gma. $8198^{\mathrm{c}}$ & 13.45 & unclassified & unknown \\
\hline Gma. $14306^{\mathrm{C}}$ & 5.68 & unclassified & pentatricopeptide (PPR) repeat-containing protein \\
\hline Gma.17451 & 16.48 & metabolism & polyubiquitin 10 protein/aging \\
\hline Gma. $8097^{\mathrm{c}}$ & 4.31 & transport & sulfate transmembrane transporter protein activity \\
\hline Gma.2213 & 6.69 & metabolism & UDP-glucoronosyl/UDP-glucosyl transferase \\
\hline Gma.26162 & 4.18 & metabolism & catalytic activity/nucleoside metabolic process \\
\hline Gma.2360 & 5.43 & metabolism & light harvesting complex of photo system II chlorophyll binding \\
\hline Gma.16710 & 12.28 & transport & phospholipid transfer protein homolg1/lipid transport \\
\hline Gma. $17162^{\mathrm{c}}$ & 15.22 & unclassified & integral membrane protein \\
\hline
\end{tabular}




\begin{tabular}{|c|c|c|c|}
\hline Gma.16916c & 10.18 & transport & Sec14 cytosolic factor family protein/ transport function \\
\hline Gma.19126c & 51.79 & metabolism & $\begin{array}{l}\text { transamidase component PIG-S phosphatidy linositol-glycan } \\
\text { biosynthesis class S protein }\end{array}$ \\
\hline Gma.30046c & 8.11 & metabolism & UDP-glycosyl transferase/para-aminobenzoic-acid metabolism \\
\hline Gma.18216c & 5.55 & unclassified & hydroxysteriod dehydrogenase 5 oxidoreductase \\
\hline Gma.1840c & 6.45 & stress response & $\begin{array}{l}\text { DNAJ heat schock N-terminal domain containing protein protein } \\
\text { folding }\end{array}$ \\
\hline Gma.27681 & 6.55 & transport & protease inhibitor protein/lipid binding/lipid transport \\
\hline Gma.6245c & 12.40 & stress response & pathogenesis related family protein \\
\hline Gma.24018c & 5.20 & metabolism & $\begin{array}{l}\text { dienelacetone hydrolase family protein hydrolase activity act on } \\
\text { carboxylic esters }\end{array}$ \\
\hline Gma.5833c & 12.56 & structural & histone H1-3/DNA binding \\
\hline Gma.3880c & 13.89 & transport & lipid transfer protein \\
\hline Gma.395c & 10.94 & cell cycle & WPP2 domain protein2/lateral root development \\
\hline Gma.31645 & 6.70 & unclassified & invertase/pectin methylestrase inhibitor family protein \\
\hline Gma.5539c & 4.59 & metabolism & chloroplast thylakoid lumen protein \\
\hline Gma.6883c & 4.90 & signaling & $\begin{array}{l}\text { disease resistance protein/ATP binding transmembrane receptor } \\
\text { activity }\end{array}$ \\
\hline Gma.34414c & 11.23 & transport & Sec14 cytosolic factor family protein \\
\hline Gma.8121 & 4.86 & metabolism & SHM7 (Serine hydroxyl methyltransferase) \\
\hline & & metabolism & glycine hydroxymethyltransferase activity \\
\hline Gma.3345c & 4.93 & metabolism & $\begin{array}{l}\text { alcohol dehydrogenase/metabolism of xenobiotics by cytochrome } \\
\text { P450 }\end{array}$ \\
\hline Gma.17306c & 6.45 & transcription factor & bzip (bzip94) transcription factor \\
\hline Gma.10882 & 4.32 & unclassified & small nuclear ribonucleoprotein/nucleic acid binding \\
\hline Gma.30979 & 5.04 & unclassified & chlorophyll a/b-binding protein \\
\hline Gma.7535c & 54.65 & stress response & $\begin{array}{l}\text { malonyl-COA: isoflavone 7-O-glucoside 6"-0-malonyl trans- } \\
\text { ferase (MT7) }\end{array}$ \\
\hline BM091947 & 4.02 & unclassified & unknown \\
\hline CD390824 & 5.54 & unclassified & unknown \\
\hline BI943856c & 4.28 & unclassified & unknown \\
\hline Gma.37041 & 5.22 & stress response & inositol pentabisphosphate 2-kinase (IPK1)/stress response \\
\hline Gma.3529 & 4.03 & unclassified & unknown \\
\hline Gma.12898c & 7.15 & unclassified & unknown \\
\hline $\mathrm{BI} 316842 \mathrm{c}$ & 4.38 & unclassified & unknown \\
\hline Gma.39401 & 5.17 & unclassified & hypothetical protein \\
\hline Gma.5555 & 4.60 & unclassified & unknown \\
\hline BM519816 & 7.02 & unclassified & unknown \\
\hline BF598929 & 8.23 & unclassified & embryodefgective3004-dehydroquinate binding/ catalytic activity \\
\hline Gma.8134 & 3.75 & metabolism & FMN adenyltransferase activity riboflavin biosynthetic process \\
\hline
\end{tabular}

${ }^{\mathrm{a}}$ significance thresholds (fold change $\left.\geq 4, \mathrm{p} \leq 0.01\right),{ }^{\mathrm{b}} \mathrm{e}$-value $(<\mathrm{e}-10)=$ the probability that the match has no biological basis, ${ }^{\mathrm{c}}$ constitutively expressed, ${ }^{\mathrm{d}}$ all genes in this table are up-regulated in PI 416937 relative to Young. Note: constitutively expressed means the gene is expressed at higher or lower level in PI 416937 relative to Young with or without aluminum treatment. 